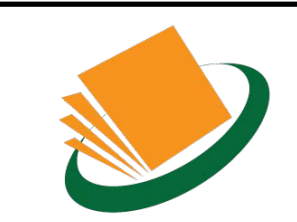

ZIBELINE INTERNATIONAL

\title{
AN EXPLORATORY STUDY ON THE RELATIONSHIP BETWEEN EXECUTIVE-EMPLOYEE COMPENSATION GAP AND ENVIRONMENTAL PERFORMANCE: EVIDENCE FROM CHINESE LISTED MANUFACTURING COMPANIES
}

\author{
Changzheng Zhang*, Yuefan Lyu, Min Li \\ Management and Economics School, Xi'an University of Technology, No 58. YanXiang Road, Xi'an, China \\ *Corresponding Author Email: Changzheng Zhang: zcz7901@163.com
}

This is an open access article distributed under the Creative Commons Attribution License, which permits unrestricted use, distribution, and reproduction in any medium, provided the original work is properly cited.

\section{ARTICLE DETAILS}

\section{Article History:}

Received 12 November 2017 Accepted 12 December 2017 Available online 1 January 2018

\section{ABSTRACT}

The paper explores the relationship between executive-employee compensation gap (EECG) and environmental performance, an ignored theoretical gap both in the field of consequences of executive compensation and the field of antecedents of environmental performance, by choosing the panel data consisting of 2320 firm-year observations in Chinese listed manufacturing companies during the period from 2011 to 2013 as the research sample. Empirical analysis based on multiple regression analysis adopting the method of OLS by applying SPSS19.0 provides a critical new finding: EECG has a negative effect on environmental performance, which holds robust with the change of the measures and the change of empirical models. Further investigation on EECG's effect mechanism on environmental performance suggests that it is the short-termism and utilitarianism derived from extra EECG that can-do harm to environmental performance.

\section{KEYWORDS}

Executive-employee compensation gap (EECG), Environmental performance, Short-termism, Tournament theory, Listed companies

\section{INTRODUCTION}

Since the Reform and Opening-up forty years ago, China's economy has achieved rapid growth. However, the rapid economic development is accompanied by a great deal of resources consumption, excessive industrial pollution and persistent ecological deterioration. As shown in "2014 China Environmental Situation Bulletin", among the 160 cities monitored, only 16 cities meet the standards of air quality, only accounting for $9.9 \%$. such a fact indicates a serious problem of Chinese environment. Though environmental pollution is derived from many factors, it mainly comes from the enterprises' production and operation activities. It is because that, on the one hand, in China the enterprises pursue too much economic interests, and on the other hand, the supervision on environmental pollution of the enterprises from the governmental authorities is rather poor. Facing the severe environmental situation, Chinese government has adopted a series of measures to carry out environmental governance by regarding enterprises as the key target of environmental governance. In addition, other stakeholders, such as investors, the public and the media, are more concerned about corporate environmental behavior than before. A study shows, enterprises in China must carry out green management, pay attention to the improvement of environmental performance, and find a "win-win" way of achieving both economic and environmental benefits [1].

Corporate governance, as a set of systematic mechanism arrangements aiming to coordinate the benefits of the company itself and its all stakeholders, affects the attitudes towards the environment of the shareholders, the top executives and the directors to a great extent, and further determines the enterprises' consciousness and development strategy of environmental protection, which will influence the environmental performance of enterprises. A number of scholars try to investigate the antecedents of environment performance from the perspective of corporate governance, and several variables have been found to have essential effects on environmental performance, which mainly include ownership structure board characteristics, the size of the board of supervisors and nature of property right, and so on $[2,3,4,5]$. Though many new findings have been made by the existing literature, there are still many other crucial variables in corporate governance whose effect on environmental performance has not been explored till now. As an example, executive-employee compensation gap (EECG) is a such ignored factor which is of great significance to be explored.
EECG, as one of the main incentive pay methods, is the key topic of corporate governance both in China and the western countries, and the wider and wider executive-employee pay disparities are receiving more and more attention from many scholars in management and economics across the world [6]. As a matter of fact, pay disparities in China have been given a great deal of attention because of the ever-growing inequality in earnings and income which has occurred over the past twenty years. EECG can reflect the allocation intention of social, financial and physical resources within a firm, and its effect on firm performance express the distribution efficiency of the various resources. EECG has key effects on rank and file employees' behavior and attitudes toward their jobs and organizations, which would make great significance to improve the organizational performance [7]. Though the performance consequences of EECG has not reached a consensus among different scholars, the view that EECG has essential effects on many organizational phenomena has been recognized by almost all literature in executive compensation. However, till now, the link between EECG and environmental performance has not been investigated.

Facing such a research gap, the study tries to make an exploratory investigation on the effect on EECG on environmental performance, aiming to enrich the theoretical contributions in the fields of EECG's consequences and environmental performance's antecedents by integrating the two research fields together. By adopting multiple regression analysis method with the data collected from the listed manufacturing companies in China over 2010-2013 as the research sample, the study concludes that EECG has a negative effect on environmental performance, and such an effect is statistically significant.

\section{LITERATURE REVIEW AND HYPOTHESIS DEVELOPMENT}

\subsection{Performance consequences of EECG}

According to the traditional opinion of a researcher, there are two main competing theoretical views on the topic of performance consequences of EECG, respectively organizational justice theory proposed by one of the researcher from the behavioral view and tournament theory proposed by a scholar from the economic view. $[8,9,10]$ And at present, scholars have not reached a consensus on the performance consequences of EECG [11]. 
cost under the conditions of more popular teamwork or knowledge coordination needs, higher compensation gap can lower the monitoring cost and thus provide strong incentives for the alignment of shareholders', employees' and executives' interests. That is to say, higher compensation gap would lead to higher firm performance at a higher possibility. Since the appearance of tournament theory created by a group of researchers, many scholars have empirically tested the positive performance consequences of compensation gap $[10,12]$. For example, one of the scholar [13] adopts coefficient of variation and CEOemployees pay gap as the measurement of compensation gap and confirms that compensation gap is positively with firm performance by taking Denmark companies as the research sample [13]. By adopting the method of ordinary least squares (OLS) regression analysis, a researcher have asserted that, for the publicly traded companies in China, compensation gap between senior executives, plays a tournament role and motivates managers to achieve higher level of performance [14]. Further ordinary least squares (OLS) regression results confirm the above result.

According to the classical social comparison theory, a critical branch of behavioral view, top executives intend to seek for distribution justice at the preconditions of both overestimating their own output and capability and weakening the input of their peers, especially the CEO [15]. According to organizational political theory, the third branch of behavioral view, since the too fierce competition among top executives and employees would be full of various political behavior, which will naturally weaken the cooperation among them, then too large compensation gap is not good to firm performance. Several empirical studies have confirmed that larger compensation gap would generate outrage of employees and managers all across the organizational levels, and such a negative effect of compensation gap on firm performance based on the behavioral theory [16]. As an example, a research using a sample of 781 U.K. companies over the period of 2000-2008, to studies the relationship between compensation gap and firm performance and speculates that British companies are actually characterized by a negative dispersion-performance relationship, i.e., the greater the compensation gap is, the worse firm performance is [17].

\subsection{Antecedents of environmental performance}

Because of the difficulty in measuring environmental performance, much literature mainly focuses on how to design the evaluation methods of environmental performance. However, rather limited literature has studied the relationship between corporate governance mechanism and environmental performance. At present, the most important domestic and foreign research results are reviewed as follows. A study [2] has found that ownership structure of a company can indirectly determine the company's environmental performance by directly affecting the response pattern to environmental pressure of the top executives. A study also suggested that institutional investors have positive effect on firm's social responsibility performance, which includes the environmental performance [18]. When they further investigate the different influence of strategic institutions and temporary institutions social responsibility performance, it is found that strategic institutions can improve the social responsibility to a higher degree. A researcher shows that the board of directors will have a significant impact on the environmental performance. [3]. To be specific, the size of the board of directors, the independence of the board of directors and the existence of Environment Committee are all positively related to the firm's environmental performance.

In China, by selecting the listed companies in the manufacturing industry over 2007-2011 as the research sample empirically prove that the proportion of state-owned shares, the proportion of independent directors, the size of the board of supervisors have significant positive impacts on the firm's environmental performance [4]. A researcher has empirically examined the relationship among the nature of property rights, ownership concentration and social responsibility [5]. The results indicate that higher ownership concentration can promote corporate social responsibility, and in state-owned enterprises, such a relationship is strengthened, while in private enterprises such a relationship is not significant. A study shows the relationship among control rights, executive incentive and environmental performance, they find that the actual controllers, no matter what types they are, have no impact on the environmental performance on the whole [19]. However, when the actual controller types are further subdivided, they conclude that when the enterprise controllers are below the level of provincial government, the environmental performance is higher than that of the other types of controllers.

Although there are relatively limited studies on the relationship between corporate governance and environmental performance both at home and abroad, it has been found that corporate governance plays an important role in improving environmental performance.

\subsection{Hypothesis development}

As shown in the above literature review, on the one hand, EECG, as a critical corporate governance variable, has potential effects on many important organizational issues which have not been explored; on the other hand, environmental performance is a critical organizational issue, which has been proved to be related to many corporate governance variables. Therefore, there is a need to investigate the relationship between EECG and environmental performance.

Greater EECG, according to the views of the tournament theory, have the function of motivating employees to work harder for greater prizes and promotions, which would result in better performance. However, according to the views of the organizational justice theory, larger EECG would stimulate the employees' sense of unfairness and being exploited by the top executives, which would lead to poor performance consequences. In practice, the two effects exit simultaneously. Motivation effect in the light of the tournament theory would make the employees know that periodic short-term performance, which is always shown as quantifiable result-oriented indicators, would determine their success or failure at work in the eyes of the top executives or their direct bosses. Any behavior or attempt by the employees, which cannot bring the firm with higher result-oriented outcomes, would be underevaluated by the managers across all levels, and thus their compensation would be lower. Moreover, if such situations happen for several times, the employees would face the risk of losing their jobs.

As an example, organizational citizenship behavior is a kind of processoriented performance indicator. In a company with too high EECG, such behavior is rather limited, since it cannot bring themselves with observable performance improvement immediately. If an employee engages themselves in organizational citizenship behavior, the formal performance system favoring large EECG would not recognize their contribution; instead, such extra effort may decline their expenditures in their daily work issues. Of course, employees would have poor intention to carry out organizational citizenship behavior when they face larger EECG. Therefore, it can be concluded that larger EECG actually reflects that the top executives' management idea has the characteristics of short-termism and utilitarianism.

The investments in environment protection of a firm need the management view of long-termism which cares about the benefits of each stakeholder of the firm, including the natural environment. Therefore, it can be proposed as follows:

\section{H1: There is a negative relationship between EECG and} environmental performance.

\section{METHOD}

\subsection{Sample}

Taking all the Chinese manufacturing A-shared listed enterprises in Shenzhen and Shanghai Stock Exchange during the year of 2010-2013 as the initial research framework to be investigated. According to the following criteria, the paper designs and chooses the suitable research sample to ensure the reliability and validity of the study. According to a study, the companies should go public before $2008(1,2)$. A study also said that the companies should run smoothly, i.e. the main businesses of the listed companies should not be changed and top executives' turnover rate should not exceed $50 \%$ and the companies should disclose all the needed data according to the research design; $(3,4)$ The compensation gap between top executives and front-line employees should not be negative.

Finally, 2320 firm-year observations are randomly selected as the research sample. Most data are selected from the Financial Research Database of CSMAR and RESSET, and part of the data are selected from the annual reports of the listed companies which can supplement the missing data and inaccurate data of the commercial research database. The descriptive statistics and correlation coefficients among research variables are shown in Table 1.

\subsection{Measures}

There are three groups of research variables in this study, respectively, explanatory variables, dependent variable and control variables. Measure of explanatory variable: Environmental performance (EP) is the explanatory variable of this study. A study shows that here is no wellaccepted measure method for EP, and different scholars adopt various measures [1]. For example, a scholar adopts whether the enterprise has 
ever been punished due to illegal discharge to measure EP, while uses the sewage charges of unit operating income and its annual change to measure EP $[20,21]$.

As an exploratory study on the effect of EECG on environmental performance, the paper adopts the context analysis method to measure environmental performance. To be specific, the authors search the term named "environmental protection (Huanjing Baohu or HuanBao in Chinese Pinyin)" in the annual report and count its number. The whole sample is sorted according to such a number. For the sample firms in the first $20 \%$ of the whole sample, EP is coded as 1 ; for the sample firms ranked from $20 \%$ to $40 \%$ in the whole sample, EP is coded as 2; for the sample firms ranked from $40 \%$ to $60 \%$ in the whole sample, EP is coded as 3; for the sample firms ranked from $60 \%$ to $80 \%$ in the whole sample, EP is coded as 4; for the sample firms ranked from $80 \%$ to $100 \%$ in the whole sample, EP is coded as 5.

Measure of dependent variable: EECG is the dependent variable in this study. One of the most popular measure methods of EECG is adopted in this study, i.e., the absolute pay gap between executives and employees (AEECG). AEECG is the difference between top executives' average cash compensation and employees' average cash compensation. Considering the non-normal distribution of AEECG, the logarithm of AEECG (LNAEECG) is adopted to make regression analysis.

Measure of control variables: According to extant literature, firm age (FAGE), firm size(LNSIZE), return on assets(ROA), ratio of the first large shareholder's shareholding(RFLS), independent director ratio (IDR) and CEO shareholding(CEOS) are selected as the control variables in this study. Among the control variables, LNSIZE and CEOS need to be clarified to a good degree. LNSIZE is the logarithm of total assets, and CEOS is coded as 1 when CEO hold shares, otherwise, CEOS is coded as 0 .

Table 1: Descriptive statistics and correlation coefficients of research variables

\begin{tabular}{|ccccccccccc|}
\hline & Mean & $\begin{array}{c}\text { Standard } \\
\text { Deviation }\end{array}$ & LNEECG & EP & LNSIZE & FAGE & ROA & RFLS & IDR & CEOS \\
\hline LNEECG & 12.813 & .813 & 1 & & & & & & & \\
EP & 3.00 & 1.413 & $-.108^{* *}$ & 1 & & & & & & \\
LNSIZE & 22.041 & 1.181 & $.393^{* *}$ & $-.143^{* *}$ & 1 & & & & & \\
FAGE & 17.020 & 5.499 & $.060^{* *}$ & $-.087^{* *}$ & $.057^{* *}$ & 1 & & & & \\
ROA & .0339 & .0606 & $.328^{* *}$ & $-.049^{*}$ & $.104^{* *}$ & .021 & 1 & & \\
RFLS & .344 & .145 & -.004 & $-.043^{*}$ & $.256^{* *}$ & $-.138^{* *}$ & $.041^{*}$ & 1 & & \\
IDR & .343 & .094 & .007 & $.041^{*}$ & $-.048^{*}$ & $-.080^{* *}$ & .023 & -.005 & 1 & \\
CEOS & .360 & .479 & $.209^{* *}$ & $-.051^{*}$ & $.073^{* *}$ & -.006 & $.123^{* *}$ & $-.189^{* *}$ & $.108^{* *}$ & 1 \\
\hline
\end{tabular}

$\mathrm{N}=2320$; ** represents significance level of 0.05 ; *** represents significance level of 0.01 .

\subsection{Model}

In order to test $\mathrm{H} 1$, multiple linear regression analysis method is adopted. Model 1 is built based on OLS as follows.

$$
\begin{aligned}
E P_{i(t+1)}= & \alpha+\delta_{1} L_{N S I Z E_{i t}}+\delta_{2} F A G E_{i t}+\delta_{3} R O A_{i t}+\delta_{4} R F L S_{i t}+\delta_{5} I D R_{i t} \\
& +\delta_{6} C E O S_{i t}+\delta L N E E C G_{i t}+\varepsilon
\end{aligned}
$$

As shown in model 1, i ranges from 1 to 2320, which represents each sample firm, and t respectively represents 2010, 2011, 2012 and 2013. If the regression coefficient of LNEECG, i.e. $\delta 7$, is significant and negative, then EECG has a negative effect on environmental performance. H1 holds.

\section{RESULTS AND DISCUSSIONS}

\subsection{Main results}

Regression results of model 1 is shown in Tab.2. Results show that Model 1 is acceptable $(\mathrm{F}=11.301, \mathrm{P}=0.000)$ and the regression coefficient of LNEECG is $-0.086(\mathrm{P}=.039)$, which is significant and negative. The fact indicates that, in the listed manufacturing companies over 2010-2013 in China, the negative effect of EECG on environmental performance exits. Hence, the enlargement of EECG in the future has its essential bad effect on environmental performance in China. H1 holds.

\begin{tabular}{|c|c|c|c|c|c|c|}
\hline \multirow{2}{*}{\multicolumn{2}{|c|}{ Model }} & \multicolumn{2}{|c|}{ Non-Standardized Coefficients } & \multirow{2}{*}{$\begin{array}{c}\text { Standardized } \\
\text { Coefficients } \\
\beta\end{array}$} & \multirow{2}{*}{$\mathrm{t}$} & \multirow{2}{*}{ Sig. } \\
\hline & & B & Standard Error & & & \\
\hline \multirow{10}{*}{ Model } & (Constant) & 7.198 & .637 & & 11.298 & .000 \\
\hline & LNSIZE & -.021 & .005 & -.080 & -3.858 & .000 \\
\hline & FAGE & -.125 & .028 & -.104 & -4.472 & .000 \\
\hline & ROA & .338 & .507 & .014 & .666 & .505 \\
\hline & RFLS & -.333 & .214 & -.034 & -1.556 & .120 \\
\hline & IDR & .514 & .308 & .034 & 1.669 & .095 \\
\hline & CEOS & -.125 & .064 & -.042 & -1.970 & .049 \\
\hline & LNEECG & -.086 & .041 & -.049 & -2.061 & .039 \\
\hline & $\mathbf{R}$ & .182 & $\mathbf{R}^{2}$ & .033 & Adjusted $\mathbf{R}^{2}$ & .030 \\
\hline & $\mathbf{F}$ & 11.301 & Model Sig. & .000 & $\mathbf{N}$ & 2320 \\
\hline
\end{tabular}

Table 2: Regression results of Model 1a a. Dependent variable: EP

\subsection{Robustness test}

In order to test the validity and reliability of the empirical result, three attempts of robustness test are executed.

First, the measure of environmental performance is changed into EP01. EP01 is coded as 1 when the appearance number of "environmental protection" in the annual report exceeds the average value of the whole sample; otherwise, EP01 is coded as 0. To substitute EP in Model 1 with EP01, Model 1* is built. The regression results of Model 1* is shown in Tab.3. As shown in Tab.3, H1 still holds.

\begin{tabular}{|c|c|c|c|c|c|}
\hline \multirow{2}{*}{ Model } & \multicolumn{2}{|c|}{$\begin{array}{l}\text { Non-Standardized } \\
\text { Coefficients }\end{array}$} & \multirow{2}{*}{$\begin{array}{c}\text { Standardized } \\
\text { Coefficients } \\
\beta\end{array}$} & \multirow[t]{2}{*}{$\mathbf{t}$} & \multirow{2}{*}{ Sig. } \\
\hline & B & Standard Error & & & \\
\hline (Constant) & 1.889 & .225 & & 8.394 & .000 \\
\hline LNSIZE & -.043 & .010 & -.101 & -4.341 & .000 \\
\hline FAGE & -.007 & .002 & -.072 & -3.450 & .001 \\
\hline ROA & .560 & 179 & .068 & 3.127 & .002 \\
\hline RFLS & -.144 & .076 & -.042 & -1.906 & .057 \\
\hline Model $1^{*}$ IDR & .401 & .109 & .076 & 3.684 & .000 \\
\hline CEOS & -.031 & .022 & -.030 & -1.380 & .168 \\
\hline LNEECG & -.033 & .015 & -.053 & -2.241 & .025 \\
\hline $\mathbf{R}$ & .188 & $\mathbf{R}^{2}$ & .035 & $\begin{array}{c}\text { Adjusted } \\
\mathbf{R}^{2}\end{array}$ & .032 \\
\hline $\mathbf{F}$ & 12.107 & Model Sig. & .000 & $\mathbf{N}$ & 2320 \\
\hline
\end{tabular}

Table 3: Regression results of Model $1 * \mathrm{~b}$

Second, the control variables are redesigned. WEST, MIDD, EPS, SSB, CAGE and LNEN are chosen as the new control variables to replace the old ones. To be specific, WEST is coded as 1 when the firm is located in the western China, otherwise, WEST is coded as 0; MIDD is coded as 1 when the firm is located in the middle area of China, otherwise, MIDD is coded as 0; EPS is earning per share; SSB is the size of the supervisory board; CAGE is the age of CEO; LNEN the logarithm of the number of employees. Model 2 is built as follows. The detailed regression results are omitted due to paper length limitation. As indicated by the results, $\mathrm{H} 1$ still holds.

$$
\begin{aligned}
E P_{i t}=\alpha & +\delta_{1} W_{E S T_{i t}}+\delta_{2} M I D D_{i t}+\delta_{3} E P S_{i t}+\delta_{4} S S B_{i t}+\delta_{5} C A G E_{i t} \\
& +\delta_{6} L N E N_{i t}+\delta L N E E C G_{i t}+\varepsilon
\end{aligned}
$$

Third, the study builds Model 3 without considering the time-lag effect. Regression results also confirm $\mathrm{H} 1$ again.

$$
\begin{aligned}
E P_{i t}=\alpha & +\delta_{1} L_{N S I Z E_{i t}}+\delta_{2} F A G E_{i t}+\delta_{3} R O A_{i t}+\delta_{4} R F L S_{i t}+\delta_{5} I D R_{i t} \\
& +\delta_{6} \operatorname{CEOS}_{i t}+\delta L N E E C G_{i t}+\varepsilon
\end{aligned}
$$

Consequently, the negative relationship between EECG and environmental performance is significant and robust, though it is rather weak in intensity.

\subsection{Discussion}

The negative effect of EECG on environmental performance indicates that extra EECG not only has the potential negative effect on firm's financial 
Consequently, the negative relationship between EECG and environmental performance is significant and robust, though it is rather weak in intensity.

\subsection{Discussion}

The negative effect of EECG on environmental performance indicates that extra EECG not onsidering the time-lag effect. Regression results also performance in micro level, but has the essential negative effect to environmental protection in macro level. On the one hand, the shorttermism management view inspired by large EECG would not provide long-term perspective required by activities in improving environmental performance; On the other hand, the competition-oriented behavior pattern enhanced by extra EECG would not provide cooperative perspective required by the cooperating behavior with all stakeholders, including the nature environment, which aims to improve environmental performance.

Accordingly, no matter for the government or the enterprises, it is needed to implement effect countermeasures to control the unlimited increase of EECG in China. If not so, not only both the smooth development of each individual firm's economic benefits and the harmony among employees within the firm would be harmed, but the environmental protection effectiveness of the whole society would be delayed.

\section{CONCLUSION}

In practice, on the one hand, facing the growing serious problem of environmental pollution in China, many countermeasures are adopted by the government to deal with it. However, the environmental pollution, especially the air pollution, gets more serious; on the other hand, facing the ever-increasing growth of EECG in China, the government and the firms have no strong motivations to limit EECG, which lead to the unlimited growth of EECG. In theory, there is a gap in linking EECG and environmental performance together. Therefore, the study tries to explore the relationship between EECG and environmental performance in order to address the practical issue by filling the theoretical gap.

Drawing on the data collected from the Chinese listed manufacturing companies over 2010-2013, the study applies multiple regression analysis and robustness test with SPSS19.0 and provides a new finding: There is a negative relationship between EECG and environmental performance, which is rather robust, though relatively weak in intensity. Such a finding is of great significance since it makes the government and practitioners know that EECG not only can affect firm performance in micro level but can determine environmental performance to a certain degree. According to this result, EECG should be paid higher intention by the scholars and the practitioners.

In the future, more empirical studies should be done in the following aspects: (1) Samples should go beyond the limitation of manufacturing companies; (2) Methods in data analysis should adopt stricter empirical models which would consider the possible endogenous problems; (3) The measure of EECG and environmental performance should be refined to a better degree according to the newest accounting practices.

\section{ACKNOWLEDGEMENTS}

This research was supported by Projects of the National Social Science Foundation of China under the Grant "15BGL109".

\section{REFERENCES}

[1]. Nutao, Y., Peirong, Y., Yan, Z. 2017. Study on the relationship among nature of property rights, corporate governance and environmental performance - Empirical test based on Chinese listed companies in chemical industry. Friends of Accounting, (14), 35-41. (In Chinese)

[2]. Murillo J.L., Ayerbe, C., Privera-To.R.R.E.S. 2008. Why do patterns of environmental response different? a stakeholders' pressure approach. Strategic Management Journal, 29(11), 1225-1240.

[3]. Walls J.L., Berrone P., Phan P. H. 2012. Corporate governance and environmental performance: is there really a link? Strategic Management Journal, 33(8), 885-913.
[4]. Xiaofei, L., Weisha, Y. 2015. Study on the relationship between corporate governance and environmental performance: Data collected from the Chinese listed manufacturing companies. Communication of Finance and Accounting, 18, 40-43.(In Chinese)

[5]. Li-li, F., Fang, L., Jia-lin, X. 2011. Nature of property rights, ownership concentration and social responsibility fulfillment. Journal of Shanxi Finance and Economic University, 33 (9), 100-107. (In Chinese)

[6]. Downes, PE., Choi, DJ. 2014. Employee reactions to pay dispersion: A typology of existing research. Human Resource Management Review, 24(1), 53-66.

[7]. Flora F.T. Chiang, Thomas A. Birtch. 2010. Pay for performance and work attitudes: The mediating role of employee-organization service value congruence. International Journal of Hospitality Management, 29 (4), 632-640.

[8]. Henderson Andrew D., Fredrickson James W. 2001. Top Management team coordination needs, and the CEO pay gap: A competitive test of economic and behavior views. Academy of Management Journal, 44(1), 96-117.

[9]. Adams, J. S. 1963. Towards an understanding of inequity. Journal of Abnormal and Social Psychology, 67, 422-436.

[10]. Lazear E.P., Rosen S. 1981. Rank-Order tournaments as optimum labor contracts. Journal of Political Economy, 89, 841-864.

[11]. Shin, T.J. 2014. Explaining pay disparities between top executives and nonexecutive employees: A relative bargaining power approach Social Forces, 92(4), 1339-1372.

[12]. Chen, J., M. Ezzamel, Ziming C. 2011. Managerial power theory, tournament theory, and executive pay in China. Journal of Corporate Finance, 17(4), 1176-1199.

[13]. Eriksson T. 1999. Executive compensation and tournament Theory: Empirical tests on Danish data. Journal of Labor Economics, 17, 262-280.

[14]. Xuan Lin, B., Lu, R. 2009. Managerial power, compensation gap and firm performance - Evidence from Chinese public listed companies. Global Finance Journal, 20(2), 153-164.

[15]. Fredrickson, J.W., Davis-Blake, A., Sanders, W.M.G 2010. Sharing the wealth: Social comparisons and pay dispersion in the CEO's top team. Strategic Management Journal, 31 (10), 1031-1053.

[16]. Byun, S. 2014. The effects of abnormal executive pay dispersion: Evidence from firm performance and executive turnover. Asia Pac J Financ Stud, 43, 621-648. doi:10.1111/ajfs.12062.

[17]. Zalewska A. 2014. Gentlemen do not talk about money: Remuneration dispersion and firm performance relationship on British boards. Journal of Empirical Finance, 27, 40-57.

[18]. Cox P., Brammer S., Millinglon A. 2004. An empirical examination of institutional investor preferences for corporate social performance. Journal of Business Ethics, 52 (1), 27- 43.

[19]. Xuan, C., Weide, C. 2013. Effect of enterprise control rights and top executives' incentive on environmental performance: Evidence from Chinese listed companies in chemical industry. Journal of Southwest University for Nationalities, 6, 160-164.(In Chinese)

[20]. Jun, L. 2012. An empirical study on the relations between environmental disclosure and environmental performance. Chinese Journal of Management, 9(12), 1856-1863.(In Chinese)

[21]. Qu-ying, H. 2012. Research on relationship between environmental performance and financial performance of Chinese listed companies. China Population, Resources and Environment, 22 (6), 23-32.(In Chinese) 